\title{
悪性リンパ腫95例の臨床的検討
}

\author{
浜口 幸吉・三吉 康郎・坂倉 康夫・鵜飼幸太郎 \\ 山際 幹和・間島 雄一・野崎 秋一
}

\section{Clinical Observation of 95 Patients with Malignant Lymphoma}

\author{
Yukiyoshi Hamaguchi, Yasuro Miyoshi, Yasuo Sakakura, \\ Kotaro Ukai, Mikikazu Yamagiwa, Yuichi Majima, Schuichi Nozaki \\ (Mie University)
}

Statistical observation of 95 patients with malignant lymphoma of the head and neck region treated for over 20 years (1961-1980) has been made.

Statistical details were as follows.

1) They included 59 males and 36 females with a male to female ratio of 1.6. Age distribution was such that the highest incidence was in the 6 th decade.

2) Twenty-nine percent of all the cases had painless swelling of cervical lymphnodes, which was the most frequent clinical sign, but most of the patients with malignant lymphoma of palatine tonsils and extra-lymphatic organs were characterised by local symptoms.

3) Waldeyer's ring involvement in which the tonsil was the most popular site was seen in $65(68 \%)$ of the 95 patients. Involvement of the nose and paranasal sinuses was not uncommon $(9.5 \%)$.

4) Stage II with lymphatic organ involvement was the most frequent (52\%), in contrast to diffuse distribution to extra-lymphatic organs.

5) In the histopathological distribution, almost all the cases were non-Hodgkin's lymphomata $(97 \%)$, of which 81 were reticulum cell sarcoma and 10, lymphosarcoma.

6) Most of the patients were treated by telecobalt or Lineac irradiated on the primary site regardless of the clinical stage. Although combined chemotherapy including MOPP, VEMP, GVP and VP was introduced from 1971 onwards, there was no criteria for indication of these modes of therapy.

7) The 5-year survival rate was $47.1 \%$ for stage I, $25 \%$ for II, $28.6 \%$ for III, $0 \%$ for IV. It was higher in lymphatic organs than in extra-lymphatic organs. There was no difference in prognosis between the treatment with or without chemotherapy.

These results indicate that lymphography, Ga scintigraphy and X-ray examination must be performed routinely before treatment in order to determine the clinical stage correctly. Regional irradiation is effective for the loco-regional stage but not effective for stage II with diffuse spreading. 


\section{はじめに}

悪性リンパ腫はリンパ組織由来の悪性腫瘍の総称であるが，その中には非常に多彩な病理組織学 的特牲をもつ腫瘍が含まれており，乙かもその細胞起源については今だに不明である。このため, 治療, 予後の基準ともなる病理組織分類, 病期分類については現在なお議論のある所である. 特に 非 Hodgkin 病に関しては, 病理像, 臨床像とも多彩であり, 病期設定, 治療方針決定上, 多くの 問題をかかえており, 各施設ごとに局所放射線療法, 化学療法の適用範囲を独自に設定して治療を 行なっているのが現況である.

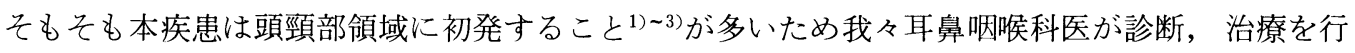
なら機会は多く, しかも全身疾患としての把握, 治療が必要である.

そこで今回, 当教室にて過去20年間に入院治療を受けた悪性リンパ腫症例について統計学的観察 を行ない，今後の診断および治療方針の方向を決定すべく，臨床的検討を行ないそれらに関する文 献的考察を加えて報告した.

\section{結}

1961年 1 月から1980年12月までの 20 年間に当 教室にて入院加療を受けた悪性リンパ腫95例 （男59例，女36例）を対象とした.

1. 性比, 年令別分布（表 1 ）

95例の性比は男1.64：女 1で，これを組織別 にみると非 Hodgkin 1.7:1（細網肉腫1.53： 1, リンパ肉腫 $2.33: 1$ ), Hodgkin $2: 1$ と男に やや多かった．年令別では全年令層に広く分布
果

し，全体および男では60才台にピークを，女で は70才台に低いピークを認めた。

\section{2 . 主訴 (表 2 )}

頸部無痛性腫脹が24例（25.3\%）と最多で, 以下咽頭痛, 咽頭異常感等といった咽喉症状を 主訴とするものがほとんどであった。これを初 発部位別にみると, 口蓋扁桃初発例では咽喉症 状（32例）が頸部腫脹（8 例）よりはるかに多か

表 1 性別, 組織的年令分布

\begin{tabular}{|c|c|c|c|c|c|c|c|c|c|c|c|c|c|}
\hline \multirow{2}{*}{ 年 令 } & \multirow{2}{*}{ 総数 } & \multirow{2}{*}{ 男 } & \multirow{2}{*}{ 女 } & \multicolumn{3}{|c|}{ RCS* } & \multicolumn{3}{|c|}{ LS** } & \multicolumn{3}{|c|}{ Hodgkin } & \multirow{2}{*}{ その他*** } \\
\hline & & & & 総数 & 男 & 女 & 総数 & 男 & 女 & 総数 & 男 & 女 & \\
\hline $0 \sim 9$ & $1(1.1)$ & $0(0)$ & $1(2.8)$ & $1(1.3)$ & 0 & 1 & $0(0)$ & 0 & 0 & 0 & 0 & 0 & 0 \\
\hline $10 \sim 19$ & $3(3.1)$ & $3(5.1)$ & $0\left(\begin{array}{ll}0 & )\end{array}\right.$ & $2(2.5)$ & 2 & 0 & $0(0)$ & 0 & 0 & 1 & 1 & 0 & 0 \\
\hline $20 \sim 29$ & $7(7.4)$ & $6(10.1)$ & $1(2.8)$ & $6(7.4)$ & 5 & 1 & $0(0)$ & 0 & 0 & 1 & 1 & 0 & 0 \\
\hline $30 \sim 39$ & $9(9.5)$ & $5(8.5)$ & $4(11.1)$ & $9(11.1)$ & 5 & 4 & $0(0)$ & 0 & 0 & 0 & 0 & 0 & 0 \\
\hline $40 \sim 49$ & $8(8.4)$ & $2(3.4)$ & $6(16.7)$ & $8(9.9)$ & 2 & 6 & $0(0)$ & 0 & 0 & 0 & 0 & 0 & 0 \\
\hline $50 \sim 59$ & $18(18.9)$ & $11(18.6)$ & $7(19.4)$ & $15(18.5)$ & 10 & 5 & $2(20)$ & 0 & 2 & 0 & 0 & 0 & 1 \\
\hline $60 \sim 69$ & $27(28.4)$ & $20(33.9)$ & $7(19.4)$ & $24(29.6)$ & 17 & 7 & $3(30)$ & 3 & 0 & 0 & 0 & 0 & 0 \\
\hline $70 \sim 79$ & $17(17.9)$ & $8(13.6)$ & $9(25.0)$ & $12(14.8)$ & 5 & 7 & $4(40)$ & 3 & 1 & 1 & 0 & 1 & 0 \\
\hline \multirow[t]{2}{*}{$80 \sim 89$} & $5(5.3)$ & $4(6.8)$ & $1(2.8)$ & $4(4.9)$ & 3 & 1 & $1(10)$ & 1 & 0 & 0 & 0 & 0 & 0 \\
\hline & $95(100)$ & $59(100)$ & $36(100)$ & $81(100)$ & 49 & 32 & $10(100)$ & 7 & 3 & 3 & 2 & 1 & 1 \\
\hline
\end{tabular}


表 2 初発部位別主訴

\begin{tabular}{|c|c|c|c|c|c|c|c|c|c|}
\hline \multirow{2}{*}{ 主 訴 } & \multirow{2}{*}{ 総 数 } & \multicolumn{4}{|c|}{ Lymphatic organ } & \multicolumn{4}{|c|}{ Extra-lymphatic organ } \\
\hline & & 口蓋扁桃 & 上咽頭 & $\begin{array}{l}\text { 頸部リン } \\
\text { 節 }\end{array}$ & 舌扁桃 & 副鼻腔 & 鼻 腔 & 甲状腺 & 頓部粘膜 \\
\hline 頸部無痛性腫脹 & $24(25.3)$ & $8(17.0)$ & $7(43.8)$ & 8 & 1 & 0 & 0 & 0 & 0 \\
\hline 咽＼cjkstart頭 & $12(12.6)$ & $10(21.3)$ & $1(6.3)$ & 0 & 1 & 0 & 0 & 0 & 0 \\
\hline 咽 頭 異 常 感 & $8(8.4)$ & $8(17.0)$ & $0\left(\begin{array}{ll}0\end{array}\right)$ & 0 & 0 & 0 & 0 & 0 & 0 \\
\hline 扁桃無痛性腫脹 & $7(7.4)$ & $7(14.9)$ & $0(0)$ & 0 & 0 & 0 & 0 & 0 & 0 \\
\hline 下 & $6(6.3)$ & $5(10.6)$ & $1(6.3)$ & 0 & 0 & 0 & 0 & 0 & 0 \\
\hline 閉 & $6(6.3)$ & $0\left(\begin{array}{ll}0 & )\end{array}\right.$ & $3(18.8)$ & 0 & 0 & 2 & 1 & 0 & 0 \\
\hline 燕 下 困 難 & $4(4.2)$ & $2(4.3)$ & $2(12.5)$ & 0 & 0 & 0 & 0 & 0 & 0 \\
\hline 煩 部 腫 脹 & $3(3.2)$ & $0(0)$ & $0\left(\begin{array}{ll}0\end{array}\right)$ & 0 & 0 & 1 & 0 & 0 & 2 \\
\hline 扁桃の白苔 & $3(3.2)$ & $3(6.4)$ & $0\left(\begin{array}{ll}0\end{array}\right)$ & 0 & 0 & 0 & 0 & 0 & 0 \\
\hline 甲＼cjkstart状＼cjkstart腺＼cjkstart腫 & $3(3.2)$ & $0\left(\begin{array}{ll}0 & )\end{array}\right.$ & $0\left(\begin{array}{ll}0\end{array}\right)$ & 0 & 0 & 0 & 0 & 3 & 0 \\
\hline い び & $2(2.1)$ & $2(4.3)$ & $0\left(\begin{array}{ll}0\end{array}\right)$ & 0 & 0 & 0 & 0 & 0 & 0 \\
\hline 煩＼cjkstart部 & $2(2.1)$ & $1(2.1)$ & $0\left(\begin{array}{ll}0\end{array}\right)$ & 0 & 0 & 1 & 0 & 0 & 0 \\
\hline
\end{tabular}

（）は\%を示す

表 3 初 発 部 位

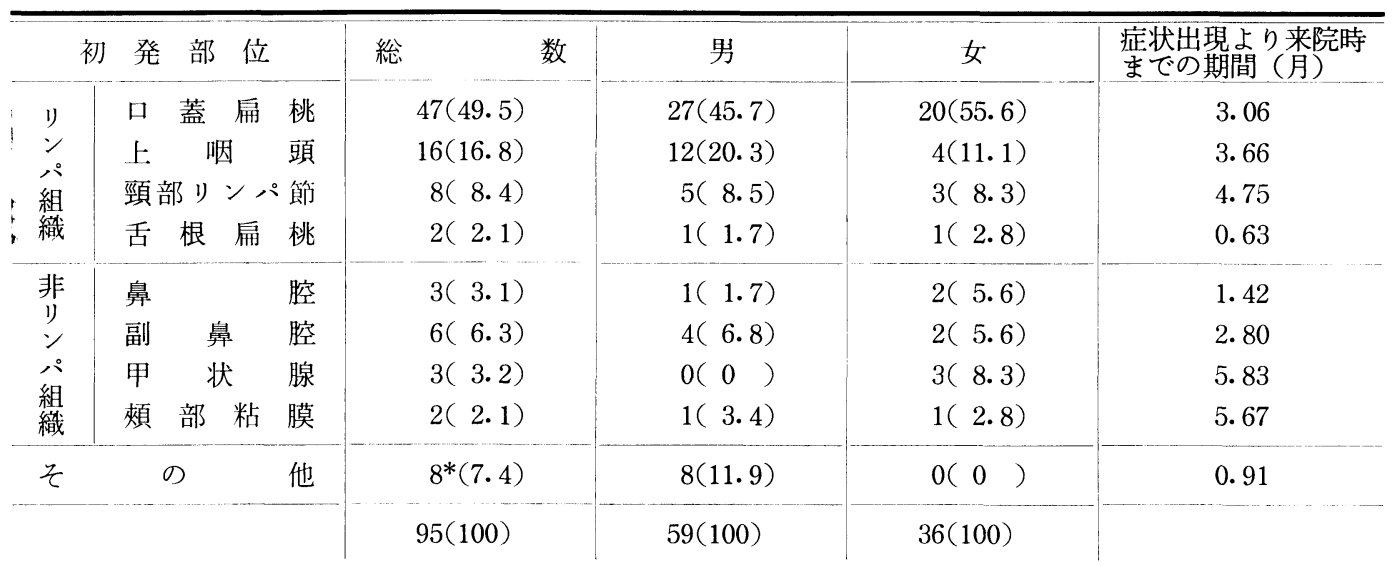

* 8 例 : リンパ組織 2 例, 非リンパ組織 6 例

( ）は\%を示す

表 4 性別, 部位別病期分布

\begin{tabular}{|c|c|c|c|c|c|c|c|c|c|c|c|c|c|c|c|}
\hline \multirow{2}{*}{ 病期 } & \multirow{2}{*}{ 総 数 } & \multirow{2}{*}{ 男 } & \multirow{2}{*}{ 女 } & \multicolumn{5}{|c|}{ Lymphatic organ } & \multicolumn{6}{|c|}{ Extra-lymphatic organ } & \multirow{2}{*}{ その他 } \\
\hline & & & & 計 & $\begin{array}{l}\text { 口蓋 } \\
\text { 扁䄻 }\end{array}$ & $\begin{array}{l}\text { 上咽 } \\
\text { 頭 }\end{array}$ & $\begin{array}{l}\text { 頸 部 } \\
\text { リンパ }\end{array}$ & $\begin{array}{l}\text { 舌扁 } \\
\text { 桃 } \\
\end{array}$ & 計 & 鼻腔 & $\begin{array}{l}\text { 副鼻 } \\
\text { 腔 }\end{array}$ & $\begin{array}{l}\text { 甲状 } \\
\text { 腺 }\end{array}$ & $\begin{array}{l}\text { 煩部 } \\
\text { 粘膜 }\end{array}$ & 口蓋 & \\
\hline I & $28(29.5)$ & $14(23.7)$ & $14(38.9)$ & 22 & 17 & 3 & 2 & 0 & 5 & 1 & 1 & 2 & 1 & 0 & 1 \\
\hline II & $47(49.5)$ & $32(54.2)$ & $15(41.7)$ & 38 & 25 & 10 & 1 & 2 & 7 & 1 & 4 & 0 & 1 & 1 & 2 \\
\hline III & $14(14.7)$ & $10(16.9)$ & $4(11.1)$ & 11 & 4 & 2 & 5 & 0 & 1 & 1 & 0 & 0 & 0 & 0 & 2 \\
\hline $\mathrm{N}$ & $6(6.3)$ & $3(5.2)$ & $3(8.3)$ & 2 & 1 & 1 & 0 & 0 & 3 & 0 & 1 & 1 & 0 & 1 & 1 \\
\hline 計 & $95(100)$ & $59(100)$ & $36(100)$ & 73 & 47 & 16 & 8 & 2 & 16 & 3 & 6 & 3 & 2 & 2 & 6 \\
\hline
\end{tabular}


ったのと比べ上咽頭では頸部腫脹の占める割合 が40\%と高かった.これに対し extra-lymphatic organ 例では, 頸部腫脹は皆無で, すべて局所 症状で占められていた。

\section{3. 初発部位（表 3 )}

Retrospective な分析を含め，また来院時に 2 力所以上の病巣があり初発部位が不明の症例 に対しては, その主要病変部位をもって初発部 位とした. Lymphatic organ では口蓋扁桃47例 (49.5\%) で最も多く, 次いで上咽頭16例 (16.8 $\%)$, 頸部リンパ節 8 例 (8.4\%), 舌根扁桃 2 例 (2.1\%) であり, Waldeyer 輪だけで65例 (68.4 \%)の多くを占めた。 また, extra-lymphatic organ では，20例中鼻副鼻腔 9 例 $(45 \%)$ およ び甲状腺 3 例, 煩部粘膜 2 例 6 で, 前者で 1 例 上咽頭への侵襲をみとめたが，原則に従い鼻副 鼻腔初発とした。また口蓋扁桃は女が，上咽頭 は男がやや割合が高く, 甲状腺は全例女であっ た. 症状出現から初診をでの期間をみると, 頸 部リンパ節が4. 75 力月と最も長く, Waldeyer 輪では約 3 力月, 鼻副鼻腔では1.4〜2. 8 力月と 最も短かかった。

\section{4. 病期分類（表 $4 \sim 7$ ）}

Retrospective な解析を含めて Ann Arbor の国際会議案に従って分類した. I 期 28 例 (29.5 \%) II 期47例 $(49.5 \%)$ ， III 期 14 例 (14.7\%) $\mathrm{N}$ 期 6 例（6.3\%）であり，性別では I 期で男 $23.7 \%$,女 $38.9 \%$ と女では I 期の症例の占める
表 5 病期別年令分布

\begin{tabular}{c|rrrr|r}
\hline 年令分布 & I & II & III & N & 計 \\
\hline $0 \sim 9$ & 0 & 0 & 0 & 1 & 1 \\
$10 \sim 19$ & 0 & 2 & 1 & 0 & 3 \\
$20 \sim 29$ & 1 & 5 & 1 & 0 & 7 \\
$30 \sim 39$ & 3 & 5 & 1 & 0 & 9 \\
$40 \sim 49$ & 3 & 2 & 3 & 0 & 8 \\
$50 \sim 59$ & 8 & 7 & 2 & 1 & 18 \\
$60 \sim 69$ & 9 & 12 & 3 & 3 & 27 \\
$70 \sim 79$ & 4 & 11 & 2 & 0 & 17 \\
$80 \sim 89$ & 0 & 3 & 1 & 1 & 5 \\
\hline 計 & 28 & 47 & 14 & 6 & 95
\end{tabular}

割合が高かった（表 4 ）。 また年令別にみると全 体に巾広い分布をみとめ, 最年少は 7 才の甲状 腺初発症例, 最高令は86才の上咽頭初発症例で あった．全症例のピークは60才代で，これに50 才代，70才代がつづいた（表 5 )。初発部位別 では, lymphatic organ と extra-lymphatic organ との間に $\mathrm{N}$ 期に拈拈いてそれぞれ 2 例 $(2.7 \%) ， 4$ 例 $(18.2 \%)$ と後者で $\mathrm{N}$ 期の占め る割合が高く，これらを器官別にみると III 期以 外は I N 期まで口蓋扁桃が最多であり， I + II 期の約 $3 / 4$ が口蓋扁桃と上咽頭とで占められ ているのに対し， III 期では14例中，口蓋扁桃 4 例, 頸部リンパ節 5 例と後者の占める割合が高 かった。 また，病期と発症より来院までの期間 との関係（表 6 ）は， I, III期で約 4 力月， II 期 2.2 力月, $\mathrm{N}$ 期 0.72 力月と $\mathrm{V}$ 期で非常に短か

表 6 病理組織別病期分布

\begin{tabular}{|c|c|c|c|c|c|c|}
\hline & \multicolumn{4}{|c|}{ 非 Hodgkin } & \multirow{2}{*}{ Hodgkin } & \multirow{2}{*}{$\begin{array}{l}\text { 症状出現より来院 } \\
\text { 時までの期間(月) }\end{array}$} \\
\hline & 総 & RCS* & $\mathrm{LS} * *$ & その 他 & & \\
\hline I & $28(29.5)$ & $25(30.9)$ & $2(20)$ & 1 & 0 & 4. 13 \\
\hline II & $47(49.5)$ & $41(50.6)$ & $5(50)$ & 0 & 1 & 2.17 \\
\hline III & $14(14.7)$ & $10(12.3)$ & $2(20)$ & 0 & 2 & 4.27 \\
\hline \multirow[t]{2}{*}{ N } & $6(6.3)$ & $5(6.2)$ & $1(10)$ & 0 & 0 & 0.72 \\
\hline & $95(100)$ & $81(100)$ & $10(100)$ & 1 & 3 & 3.23 \\
\hline
\end{tabular}

*; Reticulum cell sarcoma

**; Lymphosarcoma

（）は\%を示す 
表 7 II 期における病巣部位

\begin{tabular}{|c|c|c|}
\hline & 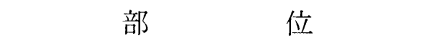 & 症例数 \\
\hline \multirow{3}{*}{ リ } & 口蓋扁桃十頸部リンパ節 & $22(46.8)$ \\
\hline & 上咽頭十頸部リンパ節 & $7(14.9)$ \\
\hline & 口蓋扁桃十上咽頭＋頸部リンパ節 & $2(4.3)$ \\
\hline ソ & 口蓋扁桃＋頸部＋腋窩 & $1(2.1)$ \\
\hline パ & 上咽頭＋頸部＋腋窩 & $1(2.1)$ \\
\hline \multirow[t]{2}{*}{ 器 } & 上咽頭＋口蓋扁桃 & $1(2.1)$ \\
\hline & 舌扁桃十頸部リンパ節 & $1(2.1)$ \\
\hline \multirow[t]{2}{*}{ 管 } & 頸部リンパ節 & $2(4.3)$ \\
\hline & その他 & $1(2.1)$ \\
\hline \multirow{4}{*}{$\begin{array}{l}\text { 非 } \\
\text { リ } \\
\text { ソ } \\
\text { 哭 } \\
\text { 器 } \\
\text { 管 }\end{array}$} & 上顎洞＋頸部リンパ節 & $3(6.4)$ \\
\hline & 鼻腔十頸部リンパ節 & $1(2.1)$ \\
\hline & 煩部粘膜＋頸部リンパ節 & $1(2.1)$ \\
\hline & その他 & $4(8.6)$ \\
\hline & & $47(100)$ \\
\hline
\end{tabular}

表 8 年度別病理組織分類

\begin{tabular}{|c|c|c|c|c|c|}
\hline \multirow{2}{*}{ 年 度 } & \multirow{2}{*}{ 総 数 } & \multicolumn{3}{|c|}{ 非 Hodgkin } & \multirow{2}{*}{ Hodgkin } \\
\hline & & RCS* & $\mathrm{LS}^{* *}$ & $\begin{array}{l}\text { unclassi- } \\
\text { fied }\end{array}$ & \\
\hline $1961 \sim 6$ & $15(15.8)$ & 14 & 1 & 0 & 0 \\
\hline $1966 \sim 70$ & $19(20)$ & 15 & 4 & 0 & 0 \\
\hline $1971 \sim 75$ & $23(24.2)$ & 20 & 1 & 0 & 2 \\
\hline $1976 \sim 8 C$ & $38(40)$ & 32 & 4 & 1 & 1 \\
\hline 計 & $95(100)$ & 81 & 10 & 1 & 3 \\
\hline
\end{tabular}

*; Reticulum cell sarcoma

**; Lymphosarcoma

（）は\%を示す
かったが，症例数が少なく参考にはできないと 考兄られる。なお而期における病巣部位沉つい て集計したところ表 7 の如く, 扁桃十頸部リン 八節 22 例 $(46.8 \%)$ ，上咽頭十頸部リンパ節 7 例 $(14.9 \%)$ と Waldeyer 輪十頸部リンパ節が 非常に多かった。

5. 病理組織学的分類 (表 1,8)

従来の細網肉腫, リンパ肉腫, Hodgkin 病の 分類および分類不能例に区分した。細網肉腫8 例 $(85.3 \%)$, リンパ肉腫10例 $(10.5 \%)$, Hodgkin 病 3 例 $(3.2 \%)$ と圧倒的に非 Hodgkin 病で 占められ，また年令別では細網肉腫は広く分布 し,リンパ肉腫は全例50才以上の高令者であっ た. 年度別では表 8 の如く, 1961年 1965年の 15例に比べて，1976〜1980年では 38 例之約 2.5 倍に增加してはいるが各組織別で特に変動は認 められなかった。

6. 治 療

治療を手術群( o 群，ただし組織生検を除く) 之非手術群に大別し, さらに放射線療法 ( $r)$, 化学療法 ( $c$, 単独薬剂療法 $c_{3}$, 多剤併用療法 $c_{\lrcorner}$) との併用の有算に上り細分し，表 9 に示し た. 非手術群の手術群に占める割合は1961年〜 65年の 1.3 を最低とし增加しており, 症例数の 增大に比して手術例は活とんど一定である。な お手術例21例中 4 例（19\%）に上顎洞開洞を施 行しており,このうち 3 例て動注を行なってい

表 9 年度別治療内容

\begin{tabular}{|c|c|c|c|c|c|c|c|c|c|c|c|c|}
\hline 度 & $\mathrm{r}$ & $\mathrm{r}+\mathrm{c}_{\mathrm{a}}$ & $\mathrm{r}+\mathrm{c}$ & $\mathrm{c}_{\mathrm{a}}$ & $\mathrm{c}_{\mathrm{b}}$ & $\mathrm{o}+\mathrm{r}$ & $\mathrm{o}+\mathrm{r}$ & $+c_{a}$ & o & $o+r+c_{b}$ & $o+c$ & 非手術／手術 \\
\hline $1961 \sim 65$ & 4 & 3 & 0 & 1 & 0 & 2 & 1 & 1 & 2 & 0 & 0 & $(1.3)$ \\
\hline $1966 \sim 70$ & 12 & 4 & 0 & 0 & 0 & 2 & 1 & 0 & 0 & 0 & 0 & $(5.3)$ \\
\hline $1971 \sim 75$ & 11 & 5 & 1 & 0 & 0 & 4 & 0 & 1 & 0 & 1 & 0 & (2.8) \\
\hline $1976 \sim 80$ & 10 & 6 & 14 & 0 & 0 & 4 & 1 & 0 & 0 & 1 & 1 & $(5.2)$ \\
\hline 計 & 37 & 18 & 15 & 1 & 0 & 12 & 3 & 2 & 2 & 2 & 1 & $72 / 21 \quad(3.4)$ \\
\hline
\end{tabular}

未治療； 2 例

$\mathrm{r}$; 放射線

$\mathrm{c}_{\mathrm{a}}$; 化学療法 (単独)

$\mathrm{c}_{\mathrm{h}}$; 多風併用療法

o ; 手術 21例




表10 化学療法の内訳

\begin{tabular}{|c|c|c|c|c|c|c|c|c|c|c|}
\hline 年 度 & 5-FU & $\mathrm{MMC}$ & $\mathrm{EX}$ & $\begin{array}{l}\text { MMC+ } \\
\mathrm{EX}\end{array}$ & BLM & VCR & MOPP & VEMP & CVP & VP \\
\hline $1961 \sim 65$ & 2 & 2 & 1 & 1 & 0 & 0 & 0 & 0 & 0 & 0 \\
\hline $1966 \sim 70$ & 5 & 0 & 0 & 0 & 0 & 0 & 0 & 0 & 0 & 0 \\
\hline $1971 \sim 75$ & 6 & 0 & 1 & 0 & 0 & 0 & 2 & 0 & 0 & 0 \\
\hline $1976 \sim 80$ & 9 & 5 & 0 & 0 & 1 & 1 & 5 & 6 & 5 & 1 \\
\hline 計 & 22 & 7 & 2 & 1 & 1 & 1 & 7 & 6 & 5 & 1 \\
\hline
\end{tabular}

5-FU ; 5-fluorouracil

MMC; mytomycin

EX ; endoxan

BLM ; bleomycin

VCR ; vincristine

表11 病期別治療内容

\begin{tabular}{|c|c|c|c|c|c|c|c|c|c|c|c|}
\hline \multirow[b]{2}{*}{ 病 期 } & \multicolumn{4}{|c|}{ 非 手 術 群 } & \multicolumn{6}{|c|}{ 手 術 群 } & \\
\hline & $\mathrm{r}$ & $c_{a}+r$ & $\mathrm{c}_{\mathrm{b}}+\mathrm{r}$ & $\mathrm{c}_{\mathrm{a}}$ & $o+r$ & $\mathrm{o}+\mathrm{r}+\mathrm{c}_{\mathrm{a}}$ & o & $o+r+c_{b}$ & $c_{a}+o$ & $c_{b}+o$ & \\
\hline I & 11 & 5 & 4 & 1 & 4 & 0 & 1 & 1 & 0 & 0 & 27 \\
\hline II & 22 & 9 & 4 & 0 & 7 & 3 & 1 & 0 & 1 & 0 & 47 \\
\hline III & 1 & 3 & 6 & 0 & 1 & 1 & 0 & 1 & 1 & 0 & 14 \\
\hline N & 2 & 0 & 1 & 0 & 1 & 0 & 0 & 0 & 0 & 1 & 5 \\
\hline 計 & 36 & 17 & 15 & 1 & 13 & 4 & 2 & 2 & 2 & 1 & 93 \\
\hline
\end{tabular}

未治療 2 例

表12 病期, 年度, 初発部位別の予後

\begin{tabular}{|c|c|c|c|}
\hline 病期 & 年 & 年 & 年 \\
\hline I & $15 / 26(57.7)$ & $11 / 21(52.4)$ & $8 / 17(47.1)$ \\
\hline II & $20 / 44(45.5)$ & $11 / 38(28.9)$ & $8 / 32(25)$ \\
\hline III & $8 / 13(61.5)$ & $4 / 11(36.4)$ & $2 / 7(28.6)$ \\
\hline N & $2 / 4(50)$ & $0 / 3(0)$ & $0 / 1(0)$ \\
\hline 計 & $45 / 87(51.7)$ & $26 / 73(35.6)$ & $18 / 57(31.6)$ \\
\hline
\end{tabular}

\begin{tabular}{|c|c|c|c|}
\hline 年. 度 & 年 & 年 & 年 \\
\hline $1961 \sim 65$ & $8 / 15(53.3)$ & $3 / 15(20 \quad)$ & $3 / 15(20$ \\
\hline $66 \sim 70$ & $7 / 19(36.8)$ & $4 / 19(21.1)$ & $4 / 19(21.1)$ \\
\hline $71 \sim 75$ & $13 / 23(56.5)$ & $12 / 23(52.2)$ & $11 / 23(47.8)$ \\
\hline $76 \sim 80$ & $17 / 30(56.7)$ & $7 / 16(43.8)$ & \\
\hline 計 & $45 / 87(51.7)$ & $26 / 73(35.6)$ & $18 / 57$ \\
\hline
\end{tabular}

\begin{tabular}{|c|c|c|c|}
\hline 初発部位 & 年 & 年 & 年 \\
\hline 口蓋扁桃 & $19 / 45(42.2)$ & $14 / 40(35)$ & $8 / 33(24.2)$ \\
\hline 上 咽 頭 & $12 / 15(80)$ & $5 / 14(35.7)$ & $3 / 11(27.3)$ \\
\hline 頸部リンパ & $5 / 8(62.5)$ & $3 / 7(42.9)$ & $3 / 7(42.9)$ \\
\hline 舌 扁 桃 & $1 / 2(50)$ & $1 / 2(50)$ & $1 / 2(50$ \\
\hline 鼻 & $1 / 2(50$ & $0 / 2(0$ & $0 / 2(0$ \\
\hline 副 鼻 腔 & $1 / 6(16.7)$ & $1 / 4(25$ & $1 / 3(33.3)$ \\
\hline 甲 状 腺 & $1 / 1(100)$ & $1 / 1(100)$ & $1 / 1(100)$ \\
\hline 頓 部 粘 膜 & $2 / 2(100)$ & $0 / 2\left(\begin{array}{ll}0\end{array}\right)$ & $0 / 1(0$ \\
\hline
\end{tabular}

（）は\%を示す 
る。 o 群では $\mathrm{o}+\mathrm{r}$ が圧倒的で (57.1\%) あり， また非手術群では $\mathrm{r}$ 単独が37例(52.1\%), 化学 療法併用が33例 $(46.5 \%)$ と注洔しく, 化学 療法単独は 1 例のみであった。なお化学療法症 例は1971年より増大しており，特に1976年以後 は単独10例に対し化学療法併用20例と著增して いる，その内容をみると表10の様に 5-FU が最 多で, endoxan, vincristine の使用例は非常に 少なかった。 また多剤併用療法は1971年以降導 入されており, 内訳は MOPP 7 例, VEMP 6 例, CVP 5 例, VP 1 例であった。病期別に みると表11の如く, I 期27例中 $\mathrm{r}$ 単独11例(40.7 $\%), \mathrm{r}+\mathrm{c} 9$ 例 (33.3\%), o 群 6 例 $(22.2 \%)$ と多剂併用療法 5 例を含めて何らかの化学療法 が加えられており，一方 III, N 期に19例中 2 例

考

悪性リンパ腫は, 我々頭頸部領域の専門医が 扱ら悪性腫瘍の中でも重要な位置を占めてお り，特に口蓋扁桃を中心とする Waldeyer 輪に 最も好発するとされている1 (3)8). ちなみに当教 室の成績をみると表 3 に示した如く, Waldeyer 輪初発例は60\%以上であった。この意味で我々 が本疾患に早期に遭遇し診断，治療する機会は 多いものと思われ，病期設定および治療方針を 中心に考察を加えた。

1. 疫学的検討

死亡診断書に基づく本邦の集計 ${ }^{9}$ によると， 悪性リンパ腫は男 1.70 :女1で，このらち Hodgkin 病では男1.96:女 1 , 非 Hodgkin 病 では男1. 66 ：女 1 と報告され，前者での性差が 指摘されている(10). 今回の我々の教室に拈ける 統計では非 Hodgkin 病で男 1.6：女 1 と諸家 の2)10)11)報告とほぼ同様の傾向を示した. 年令別 分布に関しては一般に非 Hodgkin 病では中高 年令層で漸増しているが, Hodgkin 病では15〜 40才に拉ける高いピークが欧米諸国で指摘され て扣り，本邦においても若干のピークがみられ $る^{99}$.

2. 臨床的検討
を除き，すべてに放射線療法がなされていた。

7. 予後（表12）

病期別にみると， I N 期まで 1 年生存率に 大差はないが， $3 ， 5$ 年生存率は I 期で良好で あり，逆に $\mathrm{N}$ 期での生存は皆無であった。年度 別では, 3 年と 5 年生存率は共にほぼ等しく, 症例が短期死亡と長期生存とに 2 分される傾向 がうかがわれた。またこれらは1961年〜1970年 に比し，1971年以降著しく向上してはいるが， 多剂併用療法が導入され始めた1976年以降には 特に変化はみられなかった。最後に初発部位 別にみると，上咽頭で 1 年生存率が $80 \%$ と高 く5, また逆に鼻副鼻腔を中心とする extralymphatic organ 初発例における予後は非常に 悪かった.

\section{察}

a) 主 訴

一般に, Waldeyer 輪初発例では同側または 対側の顎下, 頸部リンパ節無痛性腫脹を主訴と して来院するものが多く，また同時に喉頭異常 感, 醼下困難といった症状を伴うことも多い1 とされている，そこで今回の統計で来院時主訴 をみると,頸部リンパ節無痛性腫脹が24例(25.3 $\%$ ）と最も多く, 咽頭痛, 咽頭異常感がこれに 続いている。このうち口蓋扁桃初発例では続発 性扁桃炎, 腫瘍による圧迫症状が主体であるの に対し，上咽頭初発例では局所解剖学的関係か らみて無症状のまま経過し頸部リンパ節への侵 襲後に来院することが多いと考えられる。こ

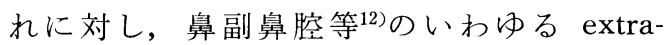
lymphatic organ 例では頸部リンパ節腫脹にて 来院する者は少なく, lymphatic organ 例とは かなり進展形式が異なるものと思われる。

b ) 病理組織学的検討

従来悪性リンパ腫は細網肉腫, リンパ肉腫 Hodgkin 病, 万胞性リンパ腫と 4 大別されてい たが1970年頃を境として非 Hodgkin, Hodgkin といら言葉が使われ始め現在では非 Hodgkin 分類として Rapapport 分類 ${ }^{13)}$ が主体となって 
いる。しかしながら古い症例を逆行して適用で きないため，我々は従来の分類を用いた，今回 の統計では細網肉腫 (85.3\%) が圧倒的であっ たが過去においては悪性リンパ腫すなわち細網 肉腫といら考えも多かったことから，むしろ非 Hodgkin として一括して扱った。

c）初発部位と進展形式

そもとも我々の身体にあるリンパ系組織は 1. lymphatic nodal structure (リンパ節) 2 . lymphatic extra-nodal structure (Waldeyer 輪, 脾, 胸腺など） 3. extra-lymphatic organ 4. extra-lymphatic site（組織中に散在するり ンパ球浸潤部位)に区分され，lymphatic と extra-lymphatic に大別でき, 両者は発生学的 にも大きく異なる ${ }^{4)}$. 従って悪性リンパ腫の進 展形式, 予後を考学る上で初発部位が lymphatic か extra-lymphatic で区別する必要があろう.今 回の統計では, lymphatic 75例/extra-lymphatic 20例（3.75:1）であり，後者のらち鼻副鼻腔 9 例が最多であった。これらを病期別にみる と, 前者では I, II 期例が多いのに比べ, 後者 では $\mathrm{I} \sim \mathbb{N}$ まで広く分布しておりしかも予後不 良の症例が多くみられる。従って両者では明ら かに進展傾向が異なるものと思われる，実際， 非 Hodgkin 病の再発症例をみると, 局所再発 が $32 \%$ であり ${ }^{14)}$, 特に extra-lymphatic 由来の ものは多中心的な性格が強く ${ }^{15)}$, むしろ局所以 外からの再発が多い。この点は治療上の大きな 問題ともなっているので治療の頃目で述べる.

\section{d ）病期分類法}

我々が採用した Ann Arbor 分類案 ${ }^{7}$ は現行 の病期分類として他の疾患とは比較できない 位複雑な本症を巧みに解決し, Hodgkin, 非 Hodgkin の両者に適用できるものである15). しかしながら II 期の設定範用の広さ, 全器官の リンパ組織を等価単位と考える点などの問題を 残している.今回の統計では, Retrospective な解析による症例も多く，またりンパ管造影, $\mathrm{Ga}$ シンチ, 胃透視等の病期決定に必要な検査 が十分でない為, 古い症例では II 期の中のかな
りのものが本来は $I I I ， \mathbb{N}$ 期に含をれているもの と推測される. 初発部位別にみると, Waldeyer 輪では圧倒的に I, II 期が多いが，頸部りンパ 節初発例では而期が最多で，腋窩および単径部 への侵襲を認めることが多い。これは症状出現 より来院までの期間が後者では長いことが十分 関係しているものと思われる。

e ）治療と予後

悪性リンパ腫は組織型を問わず radio-sensitive であり ${ }^{16)}$ ，放射線による腫瘤消失効果は高 く ${ }^{17)}$, 最も期待できる治療であるが，もちろん 正確な病期, 腫瘍進展度の把握の上にこそ良好 なる予後が得られるものである. 当教室を含 め, I , II 期に対しては従来より放射線療法単 独で行なってきた施設が多く18), 照射野の設 定および線量が適切であれば再発はみられな (19)20). しかしながら, 放射線治療後の再発例 の多くは照射野以外である21222) と言われてお り，しかも再燃後の成績は非常に悪いと報告さ れており，この点を十分考慮する必要がある。 実際，I，II期例において放射線療法に化学療 法を併用する必要性が叫ばれており ${ }^{16) 22)}$, 坂 井 ${ }^{23)}$ らは腫瘍の進展速度を重視して, 進展傾向 の著しい症例には，その病期にかかわらず積極 的に化学療法を加えることが必要であると強調 している.今回の統計をみると病期別の治療方 針が判然とせず，かつリンパ節，口蓋扁桃摘出 術などの外科的侵襲を過度に加えている例が多 い. 限局型の症例では外科的治療もみられる が，それには十分なる組織学的検討や侵襲部位 の把握(6)が必要であろう。また化学療法は, 古 い症例では vincristine, endoxan と言った代 表的抗腫瘍剂 ${ }^{24)}$ がほとんぞ使用されておらず, 1976年以降に VEMP，MOPP 等の多剂併用療 法が導入されるまでは全く皆無であったと考え られる。ささらに, 当教室では数年前より免疫療 法が開始されており，それと共に免疫学的検查 も急速に実施されつつあるのが現況である。こ の様な状況で予後との関係を検討することには 問題があるが，病期別に予後をみると I 期では 
II 期以上に比し，明らかに成績がすぐれてお り，I期の多くが放射線単独のみにて十分に完 治しえることが推測される．これに対しIII期で は 1 年と 3,5 年生存率との間に大きな差異が あり，このことは II 期の中で I 期に近く限局的 性格を示す例では放射線療法が著効を示すが, III， $\mathrm{N}$ 期に含まれる様な進展速度の著しい症例 では放射線単独では十分コントロールできずに 早期に死亡することが多いことを示しており， II 期に対する治療方針設定の難しさがらかが われる。また，鼻副鼻腔を中心とする extralymphatic organ 初発例では, I 期であっても 局所侵襲の著しい症例が多くかつ上皮性悪性腫 瘍との鑑別診断が困難であることが多い25)た め, 初診時には限局傾向が強いにもかかわらず 長期生存例が極めて少ない12)。この点, 早期の 確定的な病理組織学的診断が必要とされる.さ らに，化学療法に対する反応が病理組織型によ ってかなり異なるため，特に反応不良である diffuse histiocytic type の症例では, 多剂併用 療法の選択にも留意する必要があろら。
以上の検討より今後, 我々は本疾患の診断, 治療に関して，まず第一に，頻回の生検により 早急なる病理組織学的診断を行ない, それと平 行して病期設定のための各種検査を駆使し, lymphatic organ 例では原則として I, II 期に は放射線療法単独を行なら。しかし II 期では初 発部位および侵襲範囲, 速度について各症例ご とに検討し，化学療法併用の適用を決定する 必要があろら。これに対し, extra-lymphatic organ 例では I 期には放射線療法, 或いは鼻副 鼻腔例の場合, 開洞ならびに動注の併用も十分 期待できる ${ }^{2829)}$ 。また II 期では，その多中心的 性格を念頭において病期の追跡が必要であろ 5. III， $\mathrm{N}$ 期は，すべて化学療法の適応 ${ }^{30)}$ とな るが，多剂併用療法の選択に関しては内科医， 放射線科医との検討の上で時期を失することの ない様にすべきである。な挽疫療法に関して はあくまで補足的治療の域を出ないのが現況で あるが, 今後, 免疫学的諸検査と共に併用して ゆく方向である。

語

1961年より1980年までの 20 年間に当教室にて入院加療を受けた悪性リンパ腫95例について統計学 的検討を行ない下記の如き結果を得た。

1. 発症頻度はやや男性で多く，かつ全年令層に広く分布しており，60才台にピークがみられ た。

2. 主訴では無痛性頸部腫脹が最多であったが，口蓋扁桃および extra-lymphatic organ 初発例 では局所症状が多くみられた。

3. 口蓋扁桃初発例が $49.5 \%$ と最多で, Waldeyer 輪初発は約70\%を占めた. また extra-lymphatic organ では鼻副鼻腔 9 例が最多であった。

4. 病期では I 期 29.5\%, II 期 49.5\%， III 期14.7\%， IV 期6.3\%で， III， $\mathrm{N}$ 期の90\%が50才以上 であったＩII 期の中で Waldeyer 輪十頸部リンパ節が非常に多かった.

5. 病理組織分類では細網肉腫 $85.3 \%$, リンパ肉腫 $10.5 \%$, Hodgkin $3.2 \%$ と非 Hodgkin が圧 倒的であった.

6. 治療に打ける非手術群／手術群の割合は年度と共に増大し前者では化学療法併用が $46.5 \%$, 後者では圧倒的に放射線併用が多かった。また多剤併用療法は1971年以降導入され，近年著増して いるが，病期に応じた治療方針が十分設定されていなかった。

7. 予後については症例が短期死亡群と長期生存群とに大別される傾向があり, 特に II , III 期で著 明であり，両期の成績に逆転をみとめた. $N$ 期での 5 年生存は皆無であった. なお extra-lymphatic 
organ 初発例の予後は非常に不良であった。

文献

1）小川一誠, 堀越昇 : 悪性リンパ腫の臨床症状・臨 床検査 (診断), 合併症 -内科 $41: 384 \sim 389$, 1978.

2）橋口哲美, 他 : 副鼻腔肉腫 2 症例とその文献的考 察. 耳喉 $12: 1017 \sim 1027,1970$.

3) Brugere $M$, et al : Non-Hodgkin's malignant lymphomata of upper digestive and respiratory tract : Natural history and results of radiotherapy. Br J Cancer $31:$ 435 440, 1975.

4）金田浩一, 他：Non-Hodgkin リンパ腫の病期分 類. 臨放 $24: 1155 \sim 1164,1979$.

5）村井須美子, 他：上咽頭腫瘍の臨床的観察. 耳鼻 臨床 74 : 掲載予定.

6）堀みどり, 他：当教室20年間の口腔悪性腫湯の臨 床統計的観察. 耳鼻臨床 $74: 1025 \sim 1037,1981$.

7) Carbone PP, et al : Report of the comittee on Hodgkin's staging classification. Cancer Res 31 : 1860 1861, 1971.

8）重松康：Non-Hodgkin リンパ腫をめぐる現地点 での問題点. 臨放 24:1121 1129, 1979.

9）谷本一夫, 服部絢一：わが国におケる悪性リンパ 腫の疫学. 内科 $41: 364 \sim 368,1978$.

10）飯島宗一：はじめに, 日本の悪性リンパ腫. 癌臨 $19: 386,1973$

11) Rosenberg SA, et al: A summary of the results of a review of 405 patients with non Hodgkin's lymphomata at Stanford university. Br J Cancer 31: 168 178, 1975

12）浜口幸吉, 他 : 鼻副鼻腔悪性リンパ腫 7 症例の検 討. 耳鼻臨床 $73: 1447 \sim 1456,1980$.

13) Rappaport H, et al : Follicular lymphoma. A reevaluation of its position in the scheme of malignant lymphoma, based on a survey of 253 cases. Cancer $9: 792 \sim 821,1956$.

14) Banfi A, et al : Malignant lymphomas of Waldeyer's ring : Natural history and survival after radiotherapy. Br Med J $3: 140 \sim 143,1972$.

15）木村有郎, 大熨泰亮: 悪性リンパ腫の病期と予 後. 内科 $41: 390 \sim 396,1978$.

16）坂井保信：悪性リンパ腫の治療. 内科 $41 ： 397$ 406, 1978

17）金田浩一, 他：Non-Hodgkin リンパ腫：歴史的
背景. 臨放 $24: 1199 \sim 1206,1979$.

18）堀内淳一：治療. Non-Hodgkin リンパ腫に対す る放射線治療, 特に進展様式, 予後についての考 察. 臨放 $24: 1207 \sim 1216,1979$.

19) Fuks $Z$, Kaplan HS : Recurrence rates following radiation therapy of nodular and diffuse malignant lymphomas. Radiology $108: 179 \sim$ 185, 1974 .

20) Cox JD, et al : Irradiation in the local control of malignant lymphoreticular tumors (nonHodgkin's malignant lymphoma). Radiology $112: 179 \sim 185,1974$.

21）涌谷忠雄, 他：細網肉腫の治療成績. 耳喉 50 : $29 \sim 33,1978$.

22）真崎規江，他：Non-Hodgkin リンパ腫に対する 併用療法および再然例の治療についての考察. 臨 放 $24: 1217 \sim 1225,1979$.

23）坆井保信, 他 : 覀性リンパ腫の化学療法. 臨血 $10: 387,1969$.

24）坂野輝夫：Non-Hodgkin リンパ腫の化学療法に 関する本邦および欧米における趨勢と問題点. 臨 放 $24: 1227 \sim 1239,1979$.

25）浅野登,他: 鼻副鼻腔悪性リンパ腫の教室集計より 見大治療方針。耳鼻臨床 $65 ： 1243 \sim 1255,1972$.

26) Schein PS, et al: Potential for prolonged disease-free survival following combination chemotherapy. Blood $43: 181 \sim 189,1974$.

27）坂野輝夫，他：Non-Hodgkin リンバ腫 176 例に おける化学療法一特に Rappaport 分類と宽解効 果及び生存期間の検討を中心に一, 日血会誌 41 : 345, 1978.

28）犬山征夫, 他 : 上顎肉腫治療の現況. 耳鼻臨床 $64: 403 \sim 424,1971$.

29）斉藤等 : 副鼻腔に発生したリンパ肉腫の 1 症例. 日耳鼻 $70: 130,1967$.

30) Pouillart, M, et al : Non-Hodgkin's malignant lymphomata in adults : chemp-radiotherapy in stages III and $\mathrm{N}$. Br J Cancer $31: 505 \sim 511,1975$.

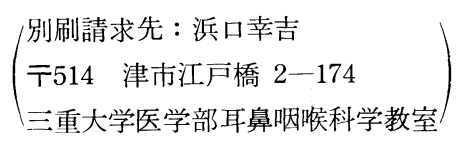

